\title{
TOTAL ACIDITY COMPARED WITH ACTUAL ACIDITY OF PLANT JUICES
}

\author{
Felix G. Gustafson
}

(Received for publication August 10, 1923)

In a recent paper ${ }^{1}$ the writer has pointed out that in many plants there is a hydrogen-ion concentration gradient. As stated in the above-mentioned paper, the gradient is not due to unequal dilution of the cell contents nor to unequal amount of $\mathrm{CO}_{2}$ dissolved in the juice. It might be due to a difference in total acidity in different parts, to an unequal distribution of basic elements, or even to differences in rate of respiration. This work is an attempt to discover whether there is any correlation between total acidity and $\mathrm{H}$-ion concentration.

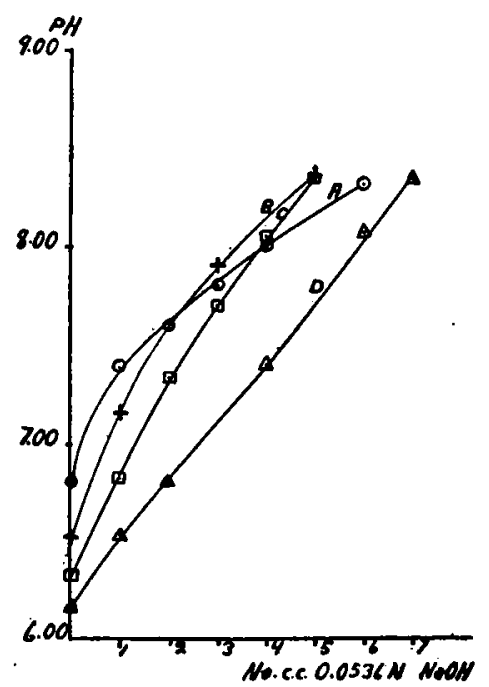

Text FIg. 2. Titration curves of the juice from the leaves of Helianthus sp. Curve $A$ represents the titration of the leaves from the first node from the base, $B$ that of the leaves from the second node, $C$ of the leaves from the third node, and $D$ of the leaves from the fourth node.

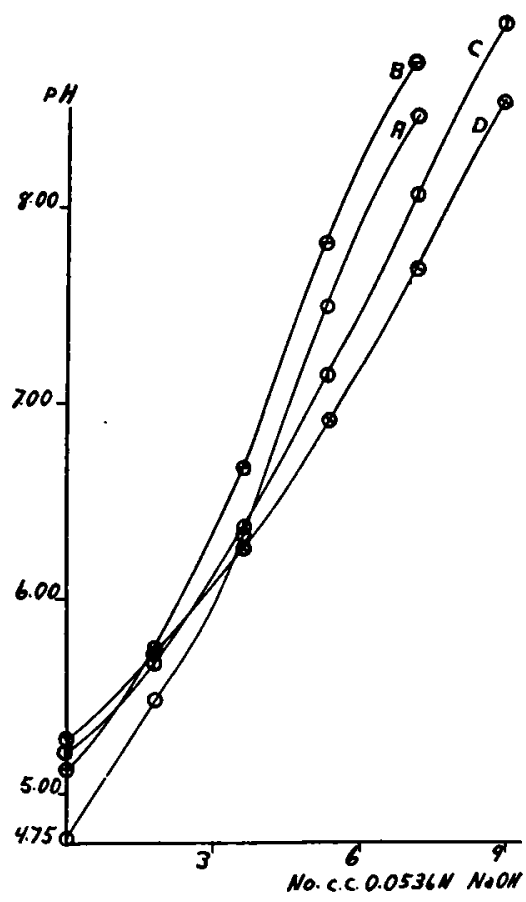

TExt Fig. I. Titration curves of the juice from $Z e a$ mais leaves. Curve $A$ represents the titration of leaves from the first node from the base of the plant, $B$ of the leaves from the third node, $C$ of the leaves from the fourth node, and $D$ of the leaves from the eighth node.

${ }^{1}$ Gustafson, F. G. Hydrogen-ion concentration gradient in plants. Amer. Jour. Bot. II : I-6. I924. 
The total acidity was determined by electric titration. Samples of Io cc. were used for each determination. The $\mathrm{pH}$ of each sample was determined before the addition of any hydroxid, and also after each addition of I cc. of $\mathrm{NaOH}$. Using these readings as points, curves were constructed illustrating the trend of neutralization as well as giving the amount of hydroxid required to neutralize the acid substances in the juice. It will be noticed by reference to the graphs that there is considerable variation in the character of the titration curves from different plants. For Zea mais, for instance, the curves are steep, while for Bryophyllum calycinum they are not nearly as steep.

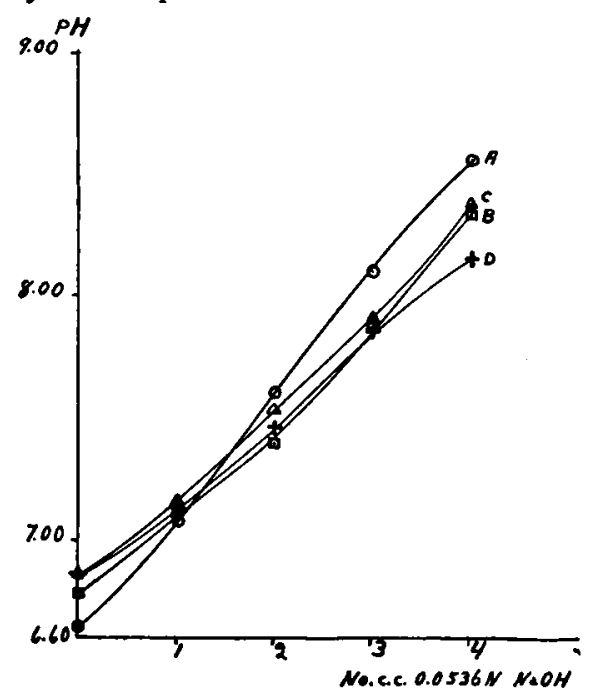

Text Fig. 3. Titration curves of juice from the leaves of Cucurbita maxima. Curve $A$ represents the titration of leaves from nodes one and two, $B$ of the leaves from nodes three and four, $C$ of the leaves from nodes five, six, and seven, $D$ of the leaves from nodes eight, nine, ten, and eleven.

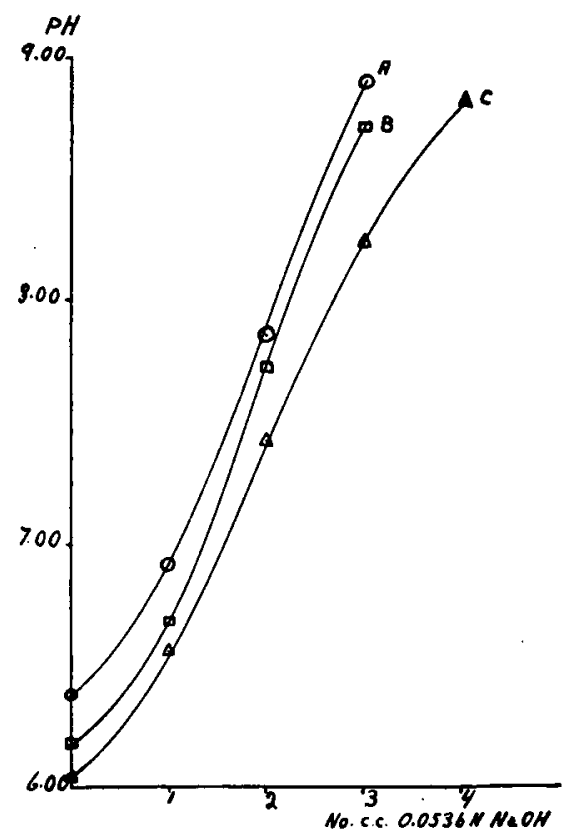

TEXT FIg. 4. Titration curves of the juice from the stem of Cucurbita maxima. Curve $A$ represents the titration of the juice from the first $10 \mathrm{~cm}$. of the stem from the base, $B$ of that from the next $18 \mathrm{~cm}$., and $C$ from the remainder of the stem.

The Zea mais plants were used at the time of tasseling, each having at that time about ten leaves all in good condition. The plants were grown in the greenhouse and were not as tall and robust as when grown out of doors, yet they were healthy plants. There was the usual H-ion concentration gradient, but there was no relation between the original $\mathrm{pH}$ of a sample of juice and the amount of hydroxid required to bring it to $\mathrm{pH} 8.3$, which was chosen as the end point. The leaves from the eighth node had originally the highest $\mathrm{pH}(5.27)$ and were already nearest the end point; yet, to reach that end point, $9 \mathrm{cc}$. of $\mathrm{NaOH}$ were required, as compared with $7 \mathrm{cc}$. for the leaves from the first node, which at the beginning was 
farthest ( $\mathrm{pH}$ 4.75) from the end point. In other words, $7 \mathrm{cc}$. of hydroxid were required to bring about a change from $\mathrm{pH} 4.75$ to 8.3 , while $9 \mathrm{cc}$. were required to change the reaction of the juice from the youngest leaves from $\mathrm{pH} 5.27$ to 8.3. Only $6.2 \mathrm{cc}$. of hydroxid were needed to neutralize io cc. of the juice from the third node; its original $\mathrm{pH}$ was 5.I3. From these data it will be seen that there is no relation between the original $\mathrm{pH}$ of the juice of corn leaves and their total acid content.

Leaves of Helianthus sp. and of Cucurbita maxima are similar to those of Zea mais in that there is no relation between $\mathrm{pH}$ and total acidity. In the

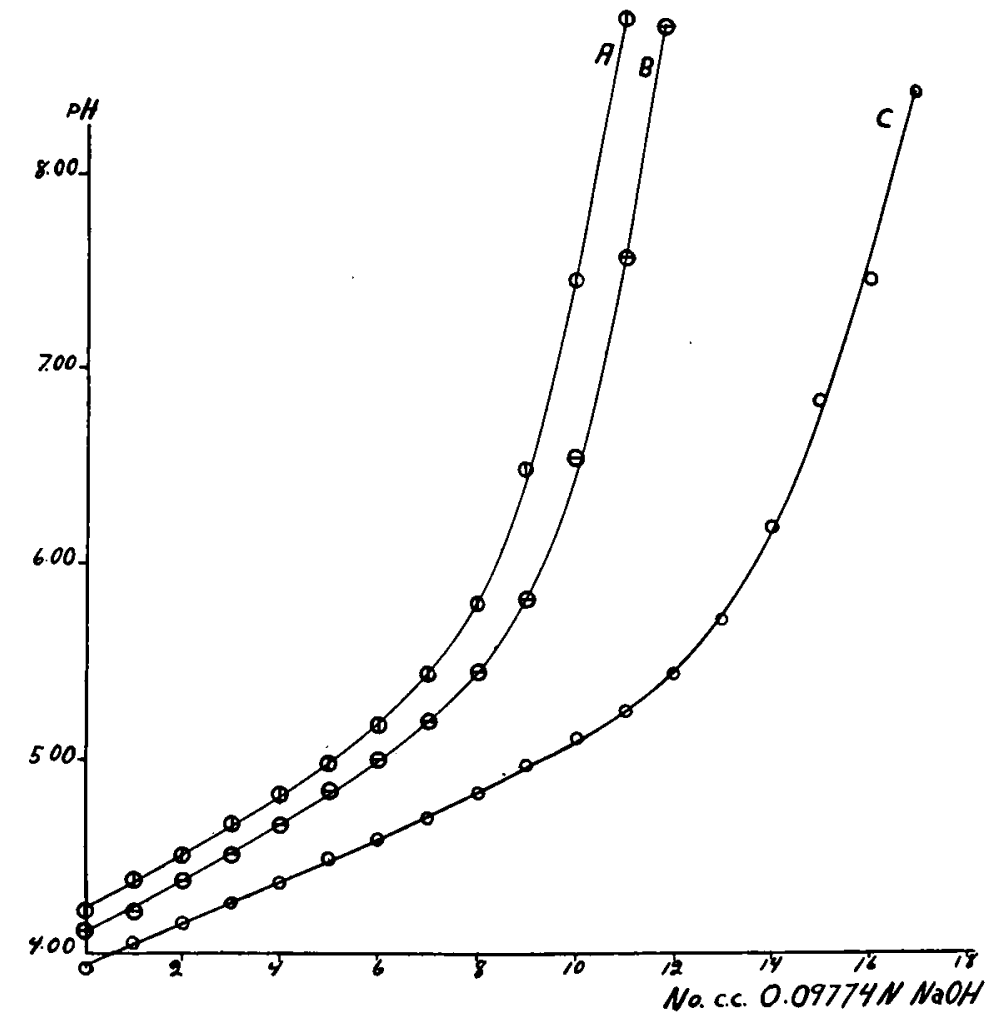

TEXT FIG. 5. Titration curves of the juice from the leaves of Bryophyllum calycinum, on a cloudy day. Curve $A$ represents the titration of the leaves from node three, $B$ from node four, and $C$ of the leaves from nodes eight and nine.

stem of Cucurbita maxima there is a relation between total acidity and $\mathrm{pH}$. That part of the stem having the highest $\mathrm{pH}$ has the lowest total acid content, and that part having the lowest $\mathrm{pH}$ has the highest total acid content.

Determinations made on the juice from the leaves of Bryophyllum calycinum during a cloudy day show a relation between $\mathrm{pH}$ and total acidity. In all instances, as the $\mathrm{H}$-ion concentration increases the total acidity also increases. On the other hand, when determinations were 
made on a clear and sunny day, there was no relation between $\mathrm{H}$-ion concentration and total acid.

Another interesting fact was brought out by the experiments on Bryophyllum calycinum; in the first experiments the oldest leaves had the highest $\mathrm{pH}$, while the youngest had the lowest $\mathrm{pH}$. In the experiments conducted during a sunny day there is a gradient of $\mathrm{H}$-ion concentration,

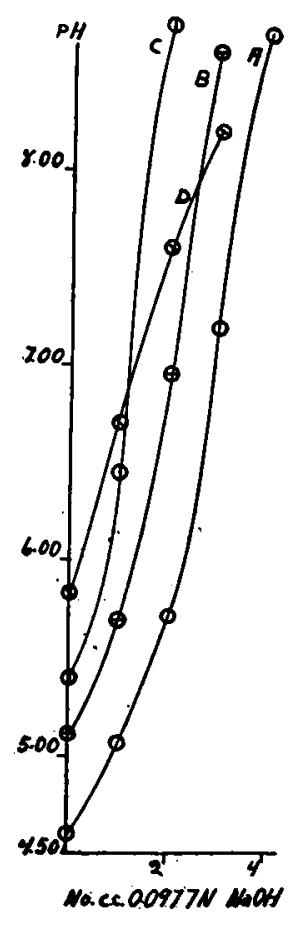

Text Fig. 6. Titration curves of the juice from the leaves of Bryophyllum calycinum on a sunny day. Curve $A$ represents the titration of leaves from node one, $B$ of the leaves from node two, $C$ of the leaves from node three, and $D$ of the leaves from node eight. but it is the reverse of that found during the cloudy day, i.e., the oldest leaves now have the lowest $\mathrm{pH}$ and the youngest leaves have the highest.

As shown by the graphs, there is a difference, both in $\mathrm{H}$-ion concentration and in total acidity, in leaves of $B$. calycinum on a cloudy day and on a bright day. The fluctuation of acidity is in agreement with the findings of Heyne ${ }^{2}$ who in 1813 wrote that in the morning the leaves of Bryophyllum (Cotyledon) calycinum are as acid to the taste as sorrel, while, as the day advances (as the light becomes more intense), they lose their acidity, being tasteless by noon. Kraus " corroborated Heyne's observations, by testing the juice from leaves of $B$. calycinum with litmus paper. As far as the writer is aware, the fluctuation in $\mathrm{H}$-ion concentration has not been reported before. The greatest fluctuation is found in the youngest leaves, where the metabolism is presumably most active, and the least in the oldest leaves.

It is worth noting that the juice from the youngest parts of all plants used, stems and leaves, requires more $\mathrm{NaOH}$ to neutralize it than the juice from the oldest part, even when the $\mathrm{pH}$ of the younger part is higher at the beginning, i.e., already nearer the end point. This would seem to indicate that the young portions of plants contain (at least in some instances) acid substances that do not dissociate as highly as those found in older parts, because, though the juice contains much total acid, yet it has not a high concentration of hydrogen ions, and a great percentage of the acid is undissociated; or the dissociation may be the same, but, the juice of the younger parts being more viscous, there is a possibility that there is a greater adsorption of the $\mathbf{H}$ ions, which on neutralization would separate from the colloidal material of the juice and then be neutralized. There is a third con-

2 Heyne, B. On the deoxidation of the leaves of Cotyledon calycinum. Trans. Linn. Soc. II: 2I3. I8I4.

${ }^{3}$ Kraus, G. Ueber die Wasservertheilung in der Pflanze IV. Die Acidität des Zellsaftes. Abhandl. Naturf. Ges. Halle 16: I54. 1883. 
tingency, namely, the greater adsorption of the hydroxyl ions by the colloids of the younger leaves.

\section{SUMMARY}

As illustrated by Zea mais, Cucurbita maxima, Helianthus sp., and Bryophyllum calycinum, the total acid of the plant juice is not responsible for the $\mathrm{H}$-ion concentration gradient found in plants. There is no constant relation between total and actual acidity in these plants.

The juice from young parts of plants requires more $\mathrm{NaOH}$ to neutralize it than does juice from older parts of the same plant, even when the former is nearer to the neutral point at the beginning than the latter.

DEPARTMENT OF BOTANY, UNIVERSITY OF MICHIGAN 